FITRAH Jurnal Kajian Ilmu-ilmu Keislaman

Vol. 04 No. 1 Juni 2018

e-ISSN : 2460-2345, p-ISSN: 2442-6997

Web: jurnal.iain-padangsidimpuan.ac.id/index.php/F

\title{
GNOSISME DAN PENGARUHNYA TERADAP PEMIKIRAN PENDIDIKAN ISLAM
}

\author{
DEDI SAHPUTRA NAPITUPULU \\ Dosen FITK UIN Sumatera Utara \\ dedisahputranapitupulu@yahoo.com
}

\begin{abstract}
Asbtract
Nowadays, One of aspect of islamic education that get the more attention and evolve is tasawuf. The thought of suifsm actually is not only followed by muslims in east region, but it also gets the best place in west region. Eventhough, many historians accused that tasawuf became the most responsible factor and became the cause of decline of islamic civilization , moreover it also becames vacum of all those. Actually tasawuf has carried out the important rule in muslims life generally and islamic education especially. This research was conducted by using descriptive analysis, those paragpraph will elaborate the development of Gnosisme in Islamic thought, figure and its monumental creation, also its influence toward islamic education's though.
\end{abstract}

Keywords: Gnosisme, Figure, creation, influence

\begin{abstract}
Abstrak
Salah satu aspek ajaran Islam yang berkembang dan mendapat perhatian dewasa ini adalah tasawuf. Ajaran para sufi ini ternyata tidak hanya diminati oleh kalangan umat Islam di wilayah Timur saja, tetapi juga mendapat tempat yang istimewa di dunia Barat. Betapapun banyak para sejarawan menuduh bahwa tasawuf menjadi faktor yang paling bertanggungjawab dan menjadi penyebab kemunduran peradaban Islam bahkan kevakuman di semua lini, tasawuf sesungguhnya telah memainkan peranan yang sangat penting dalam kehidupan umat Islam secara umumnya dan pendidikan Islam secara khusus. Dengan menggunakan analisis deskriptif, paragraf-paragraf berikut ini akan menguraikan perkembangan gnosisme dalam khazanah pemikiran Islam, tokoh dan karya monumentalnya serta pengaruhnya terhadap pemikiran pendidikan Islam.

Kata Kunci: gnosisme, tokoh, karya, pengaruh
\end{abstract}

\section{PENDAHULUAN}

Makalah ini akan penulis awali dengan kisah seorang sufi dan muridnya, kisah yang sebenarnya pernah ditulis oleh Haidar Bagir, kali ini diulang kembali dengan redaksi yang berbeda namun maksudnya sama. Syahdan, tersebutlah seorang sufi terkenal bernama Ibrahim bin Adham dari Balkh Asia Tengah. Suatu ketika beliau berjalan dengan muridnya bernama Saqiq al-Balkhi, di tengah perjalanan mereka melihat ada burung menggelepar-gelepar di tanah 
FITRAH Jurnal Kajian Ilmu-ilmu Keislaman Vol. 04 No. 1 Juni 2018

karena patah sayapnya. Sebelum mereka sempat bereaksi apa-apa, dari udara muncul burung lain menghampiri sambil membawa makanan di paruhnya. Kemudian burung itu turun dan mendekati burung yang patah sayapnya itu. Lalu dia pun memberikan makanan yang ada di paruhnya tadi. Melihat kejadian itu, Saqiq al-Balkhi berbicara seolah-olah kepada dirinya sendiri. "Ya Allah, saya ini kok takut tentang rezeki saya. Burung yang patah sayapnya saja rezekinya dijamin Allah, apalagi saya manusia yang sehat ini".

Mendengar hal itu, Ibrahim bin Adham berkata, "Wahai Saqiq! Aneh kamu ini! Mengapa hanya memperhatikan burung yang patah sayapnya dan tidak berdaya itu. Mengapa tidak kamu lihat burung yang sehat itu, karena dia sehatlah bisa mencari makan dan kemudian membantu burung malang itu". Ibra>hi>m bin Adham kira-kira ingin mengatakan mana yang lebih baik, menjadi burung yang tidak berdaya, atau menjadi burung sehat yang bisa membantu burung lainnya. Seorang sufi yang baik bukan orang yang miskin, lemah, tidak sehat kemudian akhirnya tergantung kepada orang lain. Tetapi sufi yang baik adalah sufi yang memiliki equilibrium fasilitas dunia dan akhirat.

Kisah singkat diatas paling tidak dapat memberikan reframe baru kepada kita mengenai "stigma" sufi yang sudah terlanjur lengket di kepala kebanyakan orang. Meminjam istilah Haidar Bagir, ini lah yang disebut dengan tasawuf positif. Mungkin, dan harus bagi seseorang mempunyai harta yang banyak, tetapi hartanya itu digunakan secara proporsional tidak untuk dinikmati oleh diri dan keluarganya saja, melainkan untuk memberdayakan kaum lemah. Uraian di bawah ini akan menjelaskan tasawuf yang lebih manusiawi dan mungkin boleh jadi berbeda dengan paradigma lama yang telah ada.

Gnosisme dalam terminologi Islam merupakan istilah lain dari tasawuf dan 'irfan. Sedangkan dunia Barat akrab mengenal sufi dengan misticism. ${ }^{1}$ Betapapun beda, tetapi sesungguhnya term tersebut memiliki muara yang sama yaitu sufi atau tasawuf. Istilah-istilah yang berkaitan dengan gnosisme akan dikupas tuntas dalam uraian berikut ini.

Tasawuf sesungguhnya telah menjadi bahasa Indonesia. Tasawuf diartikan sebagai ajaran dan cara untuk mengenal dan mendekatkan diri kepada

1"mysticism" secara etimologi berarti sesuatu yang misterius (some thing mysterious). Dalam bahasa Inggris, kata "mystic" mempunyai akar kata yang sama dengan mystery; keduanya berasal dari bahasa Yunani yaitu "myein" yang berarti menutup mata. Mistisisme, merupakan kecenderungan spiritual yang terdapat pada semua agama, atau kesadaran terhadap wujud yang satu. 
Allah swt. sehingga memperoleh hubungan langsung secara sadar dengan-Nya. Adapun orang-orang yang ahli dalam tasawuf dinamai dengan sufi. ${ }^{2}$ Untuk lebih mempertajam definisi tasawuf berikut ini akan dijelaskan menurut pandangan beberapa tokoh.

Komentar pertama datang dari seorang ulama kharismatik dan multi talenta, Buya Hamka. ${ }^{3}$ Menurut beliau Arti tasawuf dan asal katanya menjadi pertikaian ahli bahasa. Setengahnya berkata bahwa perkataan itu diambil dari perkataan sifa artinya suci, bersih, ibarat kilat kaca. Setengahnya lagi berkata suf artinya bulu binatang. Karena benci mereka kepada pakaian yang indah-indah, pakaian orang dunia ini. Suffah, ialah golongan sahabat-sahabat nabi yang menyisihkan dirinya di suatu tempat terpencil di samping mesjid nabi. Sufana, ialah sebangsa kayu yang mersik tumbuh di padang pasir tanah arab. Tetapi Setengah ahli bahasa dan riwayat mengatakan bahwa perkataan sufi itu bukan bahasa Arab, tetapi bahasa Yunani yang telah lama diArabkan. Asalnya theosofie. Artinya ilmu ketuhanan. Kemudian diArabkan dan diucapkan dengan lidah orang arab hingga berubah menjadi tasawuf.

Menurut pakar lainnya bahwa tasawuf berasal dari kata al-saff (barisan), al-safa' (bersih), Sophia (bijaksana), al-suffah (pelana kuda), atau al-suf (wol kasar). Tetapi menurut kebanyakan ahli agaknya yang paling mendekati kebenaran adalah al-suf (wol kasar), sebab menurut para peneliti tasawuf, orang-orang yang mempraktikkan kehidupan tasawuf itu dulu mempunyai kebiasaan berpakaian dari bahan wol kasar. Pakaian wol kasar adalah simbol dari kesederhanaan, atau bahkan kemiskinan yang anti kemewahan. Selain itu pakaian ini juga berarti simbol protes terhadap maraknya kemewahan di tengah-tengah kemiskinan rakyat. ${ }^{4}$

Menurut Abuddin Nata bahwa tasawuf adalah ajaran kerohanian dalam Islam yang telah diajarkan oleh Nabi Muhammad saw. dengan kehidupan yang sederhana $(z u h u d)$ dan peribadatannya telah dicontohkan oleh para sahabat. ${ }^{5}$ Dalam kaitannya dengan suf (kain wol), Thomas W. Lippman turut berkomentar, menurutnya sufi diartikan sebagai orang yang memakai kain wol kasar mirip dengan pakain Rahib-rahib Kristiani karena para praktisi awal sufi memakai

\footnotetext{
${ }^{2}$ Depdiknas, Kamus Besar Bahasa Indonesia (Jakarta: Balai Pustaka, 1989), hlm. 1097. ${ }^{3}$ Hamka, Tasawuf Modern (Jakarta: Pustaka Panjimas, 1983), hlm. 1.

${ }^{4}$ Komaruddin Hidayat, et al., Agama di Tengah Kemelut (Jakarta: Mediacita, 2001), hlm. 111.

${ }^{5}$ Abuddin Nata, Ilmu Kalam, Filsafat dan Tasawuf (Jakarta: Rajawali, 1994), hlm. 156.
} 
FITRAH Jurnal Kajian Ilmu-ilmu Keislaman

Vol. 04 No. 1 Juni 2018

kain ini dalam pertapaannya sejak abad ke-9. ${ }^{6}$ Senada dengan itu, Reynold A. Nicholson juga berpendapat bahwa pada awalnya terdapat kontak mengenai teori antara gnosisme Islam dengan gnosisme pada agama Kristen sehingga ada pada keduanya terdapat kemiripan. ${ }^{7}$

Secara umum tujuan tasawuf adalah mendekatkan diri kepada Allah swt. Harun Nasution berpendapat bahwa yang menjadi tujuan tasawuf adalah memperoleh hubungan langsung dan disadari dengan Tuhan sehingga disadari benar bahwa seseorang berada di khadirat Tuhan. ${ }^{8}$ Beliau menambahkan bahwa sarana untuk bisa mendekati Tuhan adalah melalui pengasingan diri dan kontemplasi. ${ }^{9}$ Sayyed Hossein Nasr turut memberikan komentarnya mengenai hal ini, menurutnya yang menjadi tujuan tasawuf adalah memungkinkan orang untuk mewujudkan kesatuan Ilahi agar selalu berada dalam kebenaran dan kembali kepada perjanjian primordial sebelumnya antara Allah dengan manusia. ${ }^{10}$

Di dalam Alquran ada banyak ayat-ayat yang menjelaskan bahwa Allah swt. sangat dekat sekali kepada hambanya. Betapapun demikian seorang hamba harus tetap mendekat kepada-Nya. Berikut adalah diantara ayat yang menjelaskan kedekatan Allah swt. dengan hamba-Nya:

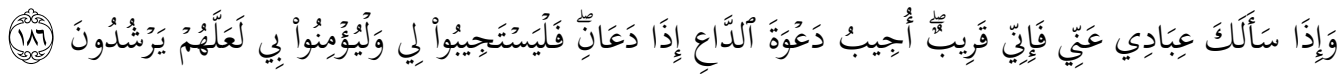

Artinya: "Dan apabila hamba-hamba-Ku bertanya kepadamu tentang Aku, Maka (jawablah), bahwasanya aku adalah dekat. aku mengabulkan permohonan orang yang berdoa apabila ia memohon kepada-Ku, Maka hendaklah mereka itu memenuhi (segala perintah-Ku) dan hendaklah mereka beriman kepada-Ku, agar mereka selalu berada dalam kebenaran". (Q.S. al-Baqarah/2: 186).

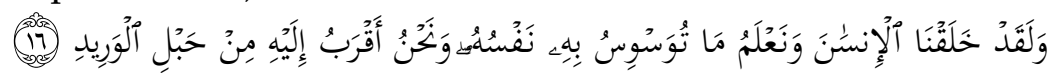

Artinya: "Dan Sesungguhnya Kami telah menciptakan manusia dan mengetahui apa yang dibisikkan oleh hatinya, dan Kami lebih dekat kepadanya daripada urat lehernya." (Q.S. Qaf/50: 16).

${ }^{6}$ Thomas W. Lippman, Understanding Islam: An Introduction to the Muslim World (New York: Penguin Group, 1995), hlm. 164.

${ }^{7}$ Reynold A. Nicholson, The Mistics of Islam (London: George Bell, 1974), hlm. 14.

${ }^{8}$ Harun Nasution, Filsafat dan Mistisme dalam Islam (Jakarta: Bulan Bintang, 1995), hlm.56. ${ }^{9}$ Harun Nasution, Islam Ditinjau dari Berbagai Aspeknya (Jakarta: UI Press, 2002), hlm. 68. ${ }^{10}$ Seyyed Hossein Nasr, Sufi Essays (USA: ABC International Group, 1999), hlm. 32. 
Singkat kata, dari beberapa definisi serta penjelasan di atas maka dapat disimpulkan bahwa tasawuf merupakan jalan untuk mendekatkan diri kepada Allah swt. (taqarrub) dengan melakukan serangkaian ritual-ritual tertentu dan mengamalkan pola hidup sederhana serta memperbanyak ibadah. Sedangkan yang menjadi tujuan dari tasawuf adalah mendekatkan diri kepada Allah. Sekali lagi, penulis ingin menegaskan bahwa prinsip dasar tasawuf adalah kesederhanaan dalam hidup demi mencapai kedekatan dengan Allah swt. bukan berarti hidup dalam serba kekurangan atau kemiskinan. Karena hakikat sufi sesungguhnya adalah bukan soal apa yang ada, tetapi sejauh mana ketergantungan terhadap apa yang ada.

Berbicara tentang epistemology Gonisme, ada baiknya dibahs terlebih dahulu tentang eistemologi. Epistemologi adalah cara memperoleh pengetahuan yang benar. ${ }^{11}$ Dalam konteks pembahasan kali ini, yang dimaksud dengan epitemologi gnosisme adalah cara mengamalkan ajaran taswuf. Tidak lengkap rasanya jika membicarakan tasawuf tanpa menyinggung tazkiyah an-Nafs, dan memang di banyak literatur juga ditemukan bahwa salah satu metode tasawuf adalah melakukan pensucian diri. Sesuci mungkin hingga tidak sedikit pun ada bercak noda, dengan itu seseorang akan memperoleh tujuan yang ia inginkan yaitu dekat dengan Tuhan.

Dalam konteks ini sesuatu yang menjadi pengetahuan mistik adalah objek-objek abstrak supra rasional seperti alam gaib, termasuk Tuhan, malaikat, surga dan neraka, juga termasuk di dalamnya seperti cinta, bahagia, susah, yakin dan sebagainya. Semua objek tersebut tidak dapat dipahami secara rasio. ${ }^{12}$ Jika demikian maka ada pertanyaan besar yang harus dijawab. Bagaimana sebenarnya cara memperoleh ilmu tasawuf?. Pengetahuan tentang tasawuf itu tidak diperoleh melalui panca indera dan tidak juga melalui akal rasional, akan tetapi pengetahuan tasawuf di peroleh melalui rasa. ${ }^{13}$ Ahmad Tafsir menambahkan bahwa untuk memperoleh ilmu tasawuf seperti yang dikuti oleh Immanuel Kant adalah menelalui moral, sebahagian berpendapat melalui insight,

${ }^{11}$ Yuyun Suriasumantri, Filsafat Ilmu: Sebuah Pengantar Populer (Jakarta: Pustaka Sinar Harapan, 1996), hlm. 100.

${ }^{12}$ Ahmad Tafsir, Filsafat Ilmu: Mengurai Ontologi, Epistemologi dan Aksiologi Pengetahuan (Bandung: Remaja Rosdakarya, 2006), hlm. 118.

${ }^{13}$ Ahmad, “Epistemologi Ilmu-ilmu Tasawuf," dalam Ilmu Ushuluddin, Vol. 14. No. 1, 2014. 
FITRAH Jurnal Kajian Ilmu-ilmu Keislaman

Vol. 04 No. 1 Juni 2018

sementara itu al-Ghazali berpendapat memperoleh ilmu tasawuf adalah melalui qalbu. ${ }^{14}$

Di dalam buku Pengantar Ilmu Tasawuf yang ditulis oleh tim penyusun Proyek Pembinaan Perguruan Tinggi Islam IAIN Sumatera Utara, bahwa cara untuk memperoleh ilmu-ilmu tasawuf adalah memahami sumber pokok ajaran Islam yang memuat landasan praktek tasawuf yaitu:

1. Alquran;

2. Hadis;

3. Sejarah hidup Nabi, Khulafau ar-Rasyidun dan para sahabat Nabi yang lain;

4. Situasi kemasyarakatan;

5. Aliran-aliran kalam. ${ }^{15}$

Dalam tasawuf akhlaki dijelaskan bahwa ada serangkaian ritual yang harus dilakukan oleh seseorang yang ingin memperoleh ilmu tasawuf:

1. Takhalli merupakan langkah pertama yang harus ditempuh dengan usaha mengosongkan diri dari sikap ketergantungan terhadap kelezatan hidup duniawi, dengan jalan menjauhkan diri dari kelezatan hidup duniawi, dengan jalan menjauhkan diri dari kemaksiatan dalam segala bentuknya dan berusaha melenyapkan dorongan hawa nafsu.

2. Tahalli merupakan langkah kedua dengan menghiasi diri dengan jalan membiasakan diri dengan sifat dan sikap serta perbuatan yang baik, berjalan sesuai dengan ketentuan agama baik yang bersifat lahir maupun batin.

3. Tajalli merupakan terungkapnya nur gaib bagi hati. ${ }^{16}$

Ada cara lain yang dapat ditempuh untuk mendapatkan sebuah pengetahuan. Cara ini sepenuhnya bersifat spiritual, tanpa hubungan apapun dengan dunia materi dan tak melibatkan proses empiris atau rasional sama sekali. Teori alternatif ini, diuraikan dengan menggunakan analogi jiwa. ${ }^{17}$ Menurut hemat penulis teori inilah yang lebih dekat dan identik dengan epistemologi tasawuf.

\footnotetext{
14 Tafsir, Filsafat, hlm. 119.

${ }^{15}$ Tim Penyusun Proyek Pembinaan Perguruan Tinggi Islam IAIN Sumatera Utara, Pengantar Ilmu Tasawuf (Medan: Naspar Djaja, t.t), hlm. 21-25.

${ }^{16}$ Tim Penyusun Proyek Pembinaan Perguruan Tinggi Islam IAIN Sumatera Utara, Pengantar Ilmu Tasawuf (Medan: Naspar Djaja, t.t), hlm. 99-110.

${ }^{17}$ Hasan Asari, Nukilan Pemikiran Islam Klasik: Gagasan Pendidikan Abu Hamid Al-Ghazali (Medan: IAIN Press, 2012), hlm. 80-81.
} 
Al-Ghazali dalam buku Nukilan Pemikiran Islam Klasik mengibaratkan hati sebagai sebuah kolam yang kosong, pengetahuan adalah ibarat air, dan indera yang lima adalah ibarat anak-anak sungai (anhar). Ada dua cara untuk mengisi kolam tersebut dengan air. Cara yang pertama adalah dengan membiarkan atau mengarahkan air kedalamnya melalui anak sungai, sampai kolam tersebut benar-benar penuh. Cara yang kedua adalah dengan menggali dasar kolam yang lebih dalam lagi sampai air memancar dari dasarnya dan mengisi kolam tersebut, pada saat yang sama semua aliran anak sungai dihentikan secara total. Demikian juga halnya, seseorang dapat memperoleh pengetahuan dengan menutup rapat kelima indranya lalu mengasingkan diri (khalwah) untuk membenahi dan meningkatkan akhlaknya, serta menyelam ke dasar jiwanya hingga mata air pengetahuan memancar dari dalam dan memenuhi hatinya. ${ }^{18}$

Singkatnya, ilmu pengetahuan tidak selalu diperoleh dengan menggunakan metode empiris dan rasional, pengetahuan juga dapat diperoleh dari Ilham sebagai anugerah Ilahi kepada siapa yang dikehendaki-Nya. Namun ini tentu tidak lah mudah, orang-orang yang dianugrahi kelebihan seperti apa yang dimaksud diatas memerlukan kualifikasi ketakwaan dan kedekatan dengan Allah swt. yang khusus. Lebih khusus lagi pada tataran tasawuf, bahwa untuk memperole hakikat sufi yang sesungguhnya, seseorang harus benar-benar bersih jiwanya (tazkiyah an-nafs).

\section{METODE PENELITIAN}

Dalam mengangkat tulisan ini penulis melakukan penelitian melalui riset pustaka, dimana penulis mengambil beberapa buku dan artikel sebagai sumber untuk dijadikan sebagai perbandingan pemikiran. Buku utama sebagai sumber dalam mengangkat tulisan ini adalah Epistemologi Ilmu-ilmu Tasawuf Ilmu Ushuluddin, Ilmu Tasawuf, Nukilan Pemikiran Islam Klasik: Gagasan Pendidikan Abu Hamid Al-Ghazali, Sufism: an Essential Introduction to the Philosophy and Practice of the Tradition of Islam, dan Tasawuf Modern, Islam: Sejarah Pemikiran dan Peradaban. Selanjutnya penulis melakukan telaah mendalam terhadap objek kajiannya, yakni gnosisme dan pengaruhnya bagi pemikiran Pendidikan Islam. hlm. 80 .

${ }^{18}$ Hasan Asari, Nukilan Pemikiran Islam Klasik: Gagasan Pendidikan Abu Hamid Al-Ghazali, 
FITRAH Jurnal Kajian Ilmu-ilmu Keislaman Vol. 04 No. 1 Juni 2018

\section{PEMBAHASAN}

\section{Perkembangan Gnosisme}

Dalam konteks pengamalan, tasawuf sesungguhnya telah telah dipraktikkan oleh Rasulullah saw. sejak awal-awal kemunculan Islam. Hal ini dapat kita lihat dari kebiasan Rasulullah saw. melakukan kontemplasi di gua Hira sampai pada iktikaf di mesjid. Lebih dari sekedar itu pola hidup Rasulullah saw. yang sangat sederhana menjadi contoh bagi generasi berikutnya. Praktikpraktik sufi semacam itu berlanjut hingga masa sahabat dan tabi'in. Perkembangan tasawuf sesungguhnya baru dimulai ketika abad ke-8 hingga abad ke-13. Mengenai hal ini akan di kaji pada sub pembahasan berikutnya.

Untuk tidak bermaksud melangkahi priodisasi sejarah perkembangan tasawuf, ada hal menarik yang patut menjadi catatan bahwa perkembangan tasawuf tidak hanya di dunia Timur atau Islam saja. Apa yang hendak penulis sampaikan bahwa perkembangan tasawuf juga terjadi di dunia Barat. Belakangan ini, dunia Barat dibanjiri ratusan buku yang terbit bagi para pencari Tuhan (salik) dan merefleksikan luasnya perspektif yang dijumpai dalam teksteks asli dari tasawuf ekstatik hingga tasawuf biasa. ${ }^{19}$ Menurut catatan Carl W. Ernst, setidaknya sejak (1750-1950 M) Eropa dan Amerika mengalihkan perhatian mereka kepada agama untuk dikaji secara serius, tasawuf menjadi bahan kajian dan rebutan antara Muslim dengan nonMuslim..$^{20}$

Sebagai contoh, di Prancis tasawuf umum diterima secara luas dikalangan kaum intelektual melalui tulisan-tulisan seorang matematikawan yang kemudian beralih menjadi metafisikawan, Rene Guenon yang juga dikenal sebagai 'Abdul Wahid (w. 1951 M) bukunya yang terkenal adalah The Crisis of the Modern World (Luzac, London, 1962), Titus Burckhardt, menulis buku An Introduction to Sufi Doctrine (Ashraf, Lahore, 1995), Henry Corbin juga turut serta membangkitkan ajaran-ajaran Ibn 'Arabi melalui karyanya Creative Imagination in the Sufism of Ibn 'Arabi (Pricenton University Press, Pricenton-NJ, 1969). Frithjof Schuon menulis buku Understanding Islam (Allen \& Unwin, London, 1963). Martin Lings dengan nama Islamnya Abu Bakar Siraj ad-Din juga menulis buku What is the Sufism? (University of California Press, Berkeley, 1975). Seorang

\footnotetext{
${ }^{19}$ Muhammad Sholikhin, Sufi Modern: Mewujudkan Kebahagiaan Menghilangkan Keterasingan (Jakarta: Kompas Gramedia, 2013), hlm. 12.

${ }^{20}$ Carl W. Ernst, Sufism: an Essential Introduction to the Philosophy and Practice of the Tradition of Islam (USA: Shambhala Publication, 1997), hlm. 1.
} 
sarjana terkemuka Iran, Sayyed Hossein Nasr juga menulis buku Sufi Essays (George Allen \& Unwin, London, 1972) dan Islamic Spirituality (Crossroad, New York, 1990)..$^{21}$

Deretan nama-nama ilmuan Barat diatas hanyalah sebahagian kecil dari orang-orang yang berjasa besar menyebarluaskan sufi di wilayah Barat. Sebagian dari mereka tetap berjuang dan konsisten untuk menjadi semacam obor di tengah gelapnya kehidupan modern dewasa ini.

\section{Tokoh dan Karya Monumental}

Masdul Hasan dalam bukunya History of Islam membagi-bagi tokoh tasawuf setiap satu abad..$^{22}$ Beliau memulai sejak abad ke-8 hingga abad ke-13 Masehi. Diantara tokoh Sufi pada abad ke-8 adalah Hasan Basri (w. 720 M), Malik bin Dinar (w. 748 M), Habib 'Azmi (w. 752 M), Ibrahim bin Adham (w. 776 M), Daud at-Ta'i (w. 777M), Sufyan as-Sauri (w. 778 M), 'Abdullah bin Mubarak (w. 797 M), Rabiah Basri (w. 801 M). ${ }^{23}$

Adapun tokoh tasawuf pada abad ke-9 adalah al-Fuzail (w. 805 M), Safiq Balkhi (w. 810 M), penulis kitab at-Tawakkul. Ma'ruf al-Karkhi (w. 815 M), Basr bin al-Haris(w. 841 M), Abu Bakar al-Sibli (w. 846 M), Ahmad bin H\{arb (w. 849 M), al-Harisbin Asad al-Muhasibi (w. 837 M), penulis kitab al-Riyah li Huquq Allah dan Kitab an-Nasihah. Hatim al-Assam (w. 852 M), Zunnun Misri (w. 861 M), Ahmad bin Khuzriyah (w. 864 M), Abu Yazid Bustami (w. 877 M), Sahal bin 'Abdullah Tustari (w. 896 M), Abu 'Abdullah at-Turmuzi (w. 898 M). ${ }^{24}$

Pada abad ke-10 tokoh-tokoh tasawuf yang terkenal adalah Ibrahim alKhawwas (w. 904 M), Abu Hasan an-Nuri (w. 908 M), Abu Qasim al-Junaid (w. 910 M), Amr bin Usman (w. 910 M), al-Hallaj (w. 922 M), penulis kitab Kitab alTawasin. Samnun (w. 928 M), al-Rudbri (w. 980 M), Ibn Khafif (w. 982 M), Abu Nasr al-Sarraj Tusi (w. 988 M), pengarang kitab al-Luma' fi Tarikh Tasawwuf. Abu Bakar al-Kalabazi (w. 995 M), penulis kitab at-Ta'aruf li mazhab ahli at-tasawwuf, dan Abu Talib al-Makki (w. 996 M), penulis kitab Qut al-Qulub. ${ }^{25}$

${ }^{21}$ Sholikhin, hlm. 12-13.

${ }^{22}$ Masdul Hasan, History of Islam: Classical Period 571-1258 C.E. (New Delhi: Adam Publisher, 2007), h. 614.

${ }^{23}$ Masdul Hasan, History of Islam: Classical Period 571-1258 C.E hlm. 614-615.

${ }^{24}$ Masdul Hasan, History of Islam: Classical Period 571-1258 C.E hlm. 615.

${ }^{25}$ Masdul Hasan, History of Islam: Classical Period 571-1258 C.E hlm.. 616. 
FITRAH Jurnal Kajian Ilmu-ilmu Keislaman Vol. 04 No. 1 Juni 2018

Sedangkan pada abad ke-11 muncul tokoh sufi seperti Abu 'Abdul Rahman Sulami (w. 1021 M), karyanya yang terkenal adalah Tabaqat as-Sufiyah. Abu Hasan al-Kharqani (w. 1034 M), Abu Nu'aym al-Isfahani (w. 1038 M), Abu Sa'id bin Abi al-Khair (w. 1040 M), Abu Qasim al-Qusyairi (w. 1072 M), diantara karyanya adalah Risalah al-Qusyairiyyah fi 'Ilm al-Taawwuf. Abu Qasim al-Gurgani (w. 1076 M), Abu 'Ali al-Farmadi al-Tusi (w. 1038 M), 'Abdullah al-Ansari (w. 1088 M), dan 'Ali al-Hajwari (w. 1092 M), penulis kitab Kasyf al-Mahzujub, Minhaj al-Din, Asrar al-khairat wa al-Ma'unat, kitab Fana' wa al-baqa, Bahar al-Qulub dan Ri'ayah li Huquq Allah. dan Abu Bakar an-Nassaj (w. 1094 M). ${ }^{26}$

Pada abad ke-12 muncul tokoh sufi besar yaitu Abu Hamid al-Ghazali (w. $1111 \mathrm{M})$, diantara karyanya yang terkenal adalah al-Daqirat fi 'Ilm al-Basirat, Ihya' ulumuddin, Minhaj al-Abidin, al-Madkhal al-Suluk ila Manazil al-Muluk, Maqasyif alQulub, Asrar al-Anwar, Nasihat al-Talamiz, Mizan al-Amal, Miskat al-Anwar, Maqasid al-Falasifah, Tahafut al-Falasifah dan al-Munqiz min ad-Dalal. Tokoh berikutnya adalah 'Abdul Qadir al-Jailani (w. 1166 M) pendiri tarekat Qadiriyah, diantara karyanya yang populer adalah al-Gunyah li at-Thalib Tariq al-Haq, Futuh al-Ghayb, Fath Rabbani dan Qasida. Selain dua tokoh tersebut masih banyak lagi tokoh lainnya yang muncul seperti: Yusuf al-Hamadani (w. $1166 \mathrm{M}$ ) beliau dikenal sebagai pendiri tarekat Naqsyabandiyah, Ah\{mad al-Yassafi (w. $1166 \mathrm{M}$ ) pendiri tarekat Yassifiyah, Ibn Kizani (w. 1167 M) pendiri tarekat Kizaniyyah, Abu Najib as-Suhrawardi (w. 1168 M) pendiri tarekat Suhrawardiyah, Ahmad bin Rifa'i (w. 1182) pendiri tarekat Rifaiyyah, Abu Madyan Suabi (w. 1107 M) dan Ainul Qudat Hamadani (w. 1131 M), karyanya yang terkenal adalah Lawa'ih. ${ }^{27}$

Adapun pada abad ke-13 tokoh sufi yang muncul adalah al-Busiri (w. 1207 M), karyanya yang terkenal adalah Qasidah al-Burdah. Najamuddin Kubra (w. 1221M) pendiri tarekat Qubrawiyah, Syihabuddin Suhrawardi (w. $1234 \mathrm{M}$ ), al-Wasiti (w. 1234 M), Ibn al-Farid (w. 1235 M), diantara karyanya adalah Nizam as-Suluk. Khawaja Muinuddin Qisti (w. 1236 M), Ibn 'Arabi (w. 1240 M), karyanya yang terkenal adalah Futuhat al-Makkiyah, Fusus al-Hikam dan sekaligus pencetus istilah Wahdat al-wujud. Al-Hariri (w. 1248 M), Abu Hasan 'Ali asSyazili (w. 1258 M) Pendiri tarekat Syaziliyah, Ruz bin maqti (w. 1270 M), pendiri tarekat Ruzbhiniyah, Jalaluddin Rumi (w. 1273 M), diantara karyanya yang terkenal adalah Masnawi dan fihi ma fihi, beliau juga pendiri tarekat Maulawiyah.

\footnotetext{
${ }^{26}$ Masdul Hasan, History of Islam: Classical Period 571-1258 C.E hlm.. 617.

${ }^{27}$ Masdul Hasan, History of Islam: Classical Period 571-1258 C.E hlm.. 619-620.
} 
Ahmad al-Badawi (w. $1276 \mathrm{M}$ ) pendiri tarekat Badawiyah, Ibrahim bin Abi alMajid al-Dasuqi (w. 1288 M), pendiri tarekat Dasuqi. ${ }^{28}$

\section{Pembagian Tasawuf}

Secara umum, mistisme Islam dibagi menjadi dua aliran yaitu tasawuf sunni (tasawuf dualistik) dan tasawuf falsafi (tasawuf monolistik). Sedangkan tasawuf sunni dibagi menjadi dua yaitu tasawuf akhlaki dan tasawuf amali. Aliran tasawuf akhlak tidak terlembagakan, dan dikenal sebagai tarekat. Sementara tasawuf falsafi berupaya memadukan visi mistis dan visi rasional. Ajaran-ajarannya memiliki kedua visi itu. Dalam aliran ini banyak terminologi filsafat digunakan. ${ }^{29}$ Uraian berikut ini akan mendeskripsikan sedikit tentang tasawuf akhlaki, 'amali dan falsafi beserta dengan tokoh dan karyanya masingmasing.

1. Tasawuf Akhlaki

Akhlak sangat erat hubungannya dengan perilaku sosial seorang hamba dalam pergaulan sehari-hari. Maka tasawuf akhlaki menjadi sangat penting karena tasawuf sendiri merupakan relasi antara manusia dengan Tuhan, sementara akhlak adalah relasi manusia antara sesama makhluk ciptaan Tuhan. Dalam relasi atara garis vertikal dan horizontal itulah tasawuf akhlaki menempati posisi yang sangat signifikan.

Meminjam istilah Nilyati, tasawuf akhlaki adalah tasawuf yang memagari dirinya dengan Alquran dan Hadis secara ketat, serta mengaitkan keadaan (ahwal) dan tingkat rohaniah (maqamat). ${ }^{30}$ Lebih lanjut Nilyati menjelaskan bahwa tasawuf akhlaki lebih berkonsentrasi pada pembinaan, pendidikan akhlak dan pengobatan jiwa melalui riyadah (latihan mental) dengan langkah takhalli, tahalli dan tajalli. ${ }^{31}$

Tasawuf akhlak ini biasanya dihubungkan dengan model pengalaman Imam Al-Ghazali (w. $1111 \mathrm{M}$ ) yang berwawasan moral-praktis dan berdasarkan kepada Alquran dan Sunnah. ${ }^{32}$ Di daerah Sumatera model tasawuf ini

${ }^{28}$ Masdul Hasan, History of Islam: Classical Period 571-1258 C.E hlm.. 620-621.

${ }^{29}$ Dja'far Siddik dan Ja'far, Jejak langkah Intelektual Islam: Epistemologi, Tokoh dan Karyanya (Medan: IAIN Press, 2010), hlm. 63.

${ }^{30}$ Nilyati, "Sistem Pembinaan ..," dalam Tajdid, Vol. 8, No. 2, 2014.

${ }^{31}$ Nilyati, "Sistem Pembinaan...," dalam Tajdid, Vol. 8, No. 2, 2014.

32 Sofyan Hadi, "Sintesa Tasawuf ...," dalam Al-Qalam, Vol. 21, No. 2, 2015 
FITRAH Jurnal Kajian Ilmu-ilmu Keislaman Vol. 04 No. 1 Juni 2018

dikembangkan oleh Nur ad-Din al-Rinari (w. 1658 M), sedangkan di Jawa ajaran tasawuf ini dikembangkan oleh para wali songo dan murid-muridnya. ${ }^{33}$

Berdasarkan uraian diatas maka dapat dianalisa bahwa tasawuf akhlaki menjadi sangat penting karena sedikit banyaknya, tasawuf sangat mempengaruhi akhlak seseorang. Orang yang serius menyelami tasawuf dapat dipastikan akan memiliki akhlak yang lebih baik dari pada orang yang hanya sekedar belajar tasawuf atau bahkan sama sekali tidak pernah memiliki pengalaman tasawuf.

2. Tasawuf 'Amali

Sebagai bagian dari tsawuf sunni, dalam konteks ini, tasawuf 'amali dilihat sebagai tarekat. Tarekat menjadi sebuah fenomena penting sejak abad ke12. Periode ini ditandai oleh perubahan pola kehidupan para sufi, dari pola individual ke pola institusional. Konsekwensinya, sejumlah kelompok sufi eksklusif muncul, dan ini dikenal sebagai tarekat. ${ }^{34}$

Di banyak literatur dijelaskan bahwa perkembangan tarekat pada awalnya hingga zaman kontemporer hari ini sangat signifikan dan masih banyak digemari. Tarekat Naqsyabandiyah misalnya, yang didirikan oleh Baha' al-Din al-Naqsyabandi (w. 1815). Selain itu ada juga Tarekat Qadiriyah yang didirikan oleh 'Abdul Qadir al-Jailani (w. 1166 M), Tarekat Suhrawardiyah yang didirikan oleh Diya' al-Din Abu Najib Suhrawardi (w. 1168 M) dan Syihab al-Din Abu Hafs 'Umar al-Suhrawardi (w. 1236 M), Tarekat Khalwatiyah yang didirikan oleh 'Umar al-Khalwati (w. 1398M), Tarekat Rifa'iyah yang didirikan oleh Ahmad Rifa'i (w. 1182 M), Tarekat Syadziliyah yang didirikan oleh Abu Hasan 'Ali asSyazili (w. 1258 M), Tarekat Tizaniyah yang didirikan oleh Ahmad al-Tijani (w. 1815 M), Tarekat Maulawiyah yang berpusat di Turki, didirikan oleh Jalal al-Din Rumi (w. 1273 M), Tarekat Chishtiyyah yang didirikan oleh Mu'in al-Din Qishti (w. $1236 \mathrm{M}$ ), Taerekat Kubrawiyyah yang didirikan oleh Nizam al-Din Kubra (w. $1221 \mathrm{M}$ ), Tarekat Ni'matullahi yang didirikan oleh Nur al-Din Syah Ni'mat Allah Wali (w. 1431M), Tarekat Sanusiyah berasal dari benua Afrika, didirikan oleh Muhammad bin 'Ali al-Sanusi (w. 1859 M), Tarekat Badawiyah yang didirikan oleh Ah\}mad al-Badawi (w. 1276 M) dan Tarekat Yasaviyah yang didirikan oleh Ah\{mad al-Yasafi (w. 1166 M). ${ }^{35}$

\footnotetext{
33 Sofyan Hadi, “Sintesa Tasawuf ...," dalam Al-Qalam, Vol. 21, No. 2, 2015.

34 Siddik dan Ja'far, Jejak..., hlm. 65.

35 Siddik dan Ja' far, Jejak..., hlm. 65-69.
} 
Sebenarnya masih banyak lagi tarekat lainnya, akan tetapi bukan disini tempatnya untuk menguraikan lebih jauh lagi. Patut dicatat bahwa masingmasing tarekat sebagaimana yang telah diungkapkan pada bagian terdahulu memiliki karakteristik amalan masing-masing. Tetapi perlu juga diingat bahwa tujuan dari semua tarekat tersebut adalah satu, yaitu mendekatkan diri kepada Allah swt. dengan sedekat-dekatnya.

Hasrat untuk mendekatkan diri kepada Allah swt. merupakan tujuan utama seorang sufi, akan tetapi tidak gampang melaukukannya. Oleh karena itu perlu jalan menuju kedekatan kepada Allah swt. Dilihat dari sisi amalan yang biasa dilakukan oleh seorang sufi, Ahmad membagi amalan tersebut kepada empat:

a. Syariat, yaitu amalan-amalan yang lahir yang di wajibkan dalam agama, atau mengikuti agama Tuhan dengan mengerjakan perintahnya dan menjauhi larangannya.

b. Tarikat, yakni mengamalkan agama dengan apik, teliti dan sungguh-sungguh serta melatih diri dengan mengerjakan ibadah yang payah-payah dengan penuh kesabaran dan melapangkan hati dari keimbangan untuh beribadah kepada Tuhan.

c. Hakikat, adalah sampainya maksud dan memandang Allah dan terbukanya hijab sehingga mampu memandang Allah dengan mata hatinya.

d. Ma'rifat, adalah terhimpunnya tiga perkara diatas dengan pengenalan yang sebenarnya dengan Allah melalui hati sanubari. ${ }^{36}$

Sedangkan menurut kitab Risalah al-Qusyairiyah sebagaimana yang dikutip oleh Ahmad, cara atau jalan mendekatkan diri kepada Allah ada dua macam; pertama, melalui apa yang disebut dengan Maqamat, yaitu jalan panjang dan berat melakukan bermacam usaha dan amal baik yang bersifat zahir maupun batin dengan tahapan-tahapan tertentu disebut dengan maqam, semuanya itu dilalui dengan mujahadah dan selalu sibuk dengan berbagai Riyadah. ${ }^{37}$ Menurut Harun Nasution sebahagian sufi berpendapat bahwa tahapan-tahapan yang harus dilalui adalah; taubat, zuhud, wara', Faqir, sabar, tawakkal dan rido. ${ }^{38} \mathrm{Kedua}$, melalui al-Ahwal yaitu situsi kejiwaan yang diperoleh

\footnotetext{
${ }^{36}$ Ahmad, Epistemologi..., hlm. 63-64.

${ }^{37}$ Ahmad, Epistemologi..., hlm. 64.

${ }^{38}$ Nasution, Filsafat..., hlm. 62.
} 
FITRAH Jurnal Kajian Ilmu-ilmu Keislaman

Vol. 04 No. 1 Juni 2018

seseorang sebagai karunia Allah swt. bukan dari hasil usahanya. ${ }^{39}$ Terdapat perbedaan dikalangan sufi, mengenai tingkatan al-Ahwal namun yang paling populer adalah; al-Muqarrabah, al-Khauf, al-Raja', al-Syauq, al-Uns, al-Tuma'ninah, al-Musyahadah dan al-Yakin. ${ }^{40}$

3. Tasawuf Falsafi

Tasawuf falsafi adalah suatu tasawuf yang bercampur dengan ajaran filsafat yang menonjolkan ungkapan ganjilnya dalam ajaran yang dikembangkan oleh para sufi. Tasawuf falsafi mulai muncul pada abad ke-3 dan abad ke-4, namun pada abad ke-5 mengalami kemunduran dan kembali bersinar pada abad ke- $6 .^{41}$ Karakteristik tasawuf falsafi secara umum ialah mengandung kesamaran akibat banyaknya ungkapan dari peristilahan khusus yang hanya dapat dipahami oleh mereka yang memahami ajaran tasawuf jenis ini. Ajaran tasawuf ini tidak dapat dipandang sebagai filsafat murni karena ajaran dan metodenya didasarkan pada rasa (zhauq) dan juga tidak bisa dikatakan bahasa dan terminologi filsafat. ${ }^{42}$

Tasawuf falsafi merujuk pada konsep tasawuf yang dihubungkan ajaran wahdatul wujud yang digagas oleh Ibn 'Arabi (w. 1240 M) dan disebut sebagai konsep sufistik yang dipengaruhi oleh aliran mistik luar Islam, terutama Yunani. ${ }^{43}$ Di Nusantara khususnya di wilayah Sumatera tasawuf model ini di pelopori oleh Hamzah Fansuri (w. 1600 M), Syamsuddin al-Sumatrani (w. 1629 M) dan 'Abdul Rauf as-Singkili (w. 1693 M). Di daerah Jawa di populerkan oleh Syekh Siti Jenar (w. 1517 M). ${ }^{44}$

Salah satu tokoh besar tasawuf falsafi adalah al-Hallaj (w. $913 \mathrm{M}$ ) yang terkenal melalui teori teori hulul (Tuhan dapat menempati tubuh manusia setelah sifat-sifat kemanusian dilenyapkan). Adalah benar bahwa bukan di sini tempatnya untuk mengurai lebih dalam lagi mengenai konsep tasawuf falsafi. Singkat kata, tasawuf falsafi merupakan kombinasi antara tasawuf dan filsafat, epistemologinya menggunakan rasa, namun penjabarannya menggunakan rasio.

\footnotetext{
${ }^{39}$ Ahmad, Epistemologi..., hlm. 64.

${ }^{40}$ Nasution, Filsafat..., hlm. 63.

${ }^{41}$ Rosihon Anwar dan Mukhtar Solihin, Ilmu Tasawuf (Bandung: Pustaka Setia, 2000), h.

42 Rosihon Anwar dan Mukhtar Solihin, Ilmu, hlm. 65.

43 Sofyan Hadi, Sintesa..., hlm. 336.

${ }^{44}$ Sofyan Hadi, Sintesa..., hlm. 336.
} 69. 
Jadi tidak dapat dipahami hanya sebatas tasawuf saja, atau memahaminya dengan menggunakan rasio semata.

\section{Pengaruh Gnosisme Terhadap Pendidikan Islam}

Jujur saja, bagian ini merupakan bagian tersulit dalam proses penulisan makalah ini karena memang secara eksplisit tidak ditemukan di berbagai literatur. Kalau pun ada sangat sedikit sekali. Uraian berikut ini adalah murni hasil ijtihad semata, dengan pertimbangan jika benar mendapatkan pahala dua, tetapi jika ternyata salah masih tetap mendapat pahala satu, sembari menunggu komentar konstruktif dari pembaca lainnya.

Pada abad ke-8 hingga abad ke-13 Masehi sebagaimana telah dijelaskan pada bagian terdahulu merupakan awal dan puncak perkembangan tasawuf. Pada saat sama justru peradaban Islam mengalami keterpurukan dan kevakuman di berbagai bidang. Membicarakan siapa yang salah merupakan bagian yang paling tidak enak, namun demikian sejarah tetaplah sejarah yang dipandang sebagai sebuah ukuran kebenaran. Sejarah harus objektif menceritakan apa adanya.

Sesungguhnya stagnasi peradaban Islam pada masa kemunduran dapat dilihat dari dua faktor; pertama, faktor internal yaitu mandegnya semangat berfikir ilmiah, meminjam istilah Fazlur Rahman "penutupan pintu ijtihad" yang ditandai dengan ditinggalkannya pelajaran-pelajaran yang bersifat logika atau ilmu-ilmu aqliyah dan filsafat pada masa khalifah Al-Mutawakkil, setelah sebelumnya berkembang pesat pada masa khalifah Al-Makmun. Alih-alih memperbaiki keadaan, dalam situasi seperti ini perhatian umat Islam dalam porsi yang cukup besar beralih kepada tarekat dan sufi. Akibatnya sikap fatalisme bersarang di hati umat Islam kala itu. Umat Islam hanya sibuk mengurusi kedekatan dengan Tuhan sampai lupa diri membangun peradaban. Selain itu kebiasaan bernostalgia dengan sejarah menjadi andalan, bahwa dahulu Islam pernah jaya dan menguasai dua per tiga bumi ini, tetapi sama sekali tidak ada usaha nyata yang muncul untuk merebut kembali masa kejayaan tersebut.

Faktor kedua adalah faktor eksternal yaitu faktor yang berasal dari luar Islam. Hal ini ditandai dengan runtuhnya Dinasti Abbasiyah pada abad ke-13 oleh serangan Mongol. Tragisnya, tidak lama setelah itu, mayoritas Negaranegara Islam juga di jajah oleh Barat. Politik dan kekuasan merupakan salah satu faktor yang mempengaruhi keberhasilan pendidikan. Tidak hanya pendidikan, 
FITRAH Jurnal Kajian Ilmu-ilmu Keislaman Vol. 04 No. 1 Juni 2018

semua lini akan terkena imbasnya jika umat Islam tidak mempunyai kekuasaan. Lagi-lagi umat Islam hanya bisa mengenang kejayaan Islam zaman klasik, bukan hanya pada masa kemunduran tetapi hingga hari ini masih banyak umat Islam yang tenggelam terlalu dalam mengenang romantika sejarah.

Berdasarkan uraian diatas, agaknya kemunculan tasawuf menjadi penyebab utama dari kemunduran peradaban Islam dalam segala bidang, hal ini dikarenakan tasawuf dalam perspektif orang-orang terdahulu, tepatnya saat awal-awal kemunculannya, dipahami sebagai sifat ekstatik-metafisis atau mistisfilosofis. ${ }^{45}$ Dengan kata lain umat Islam ketika itu memang sedang dalam masa kemunduran, jadi jalan hidup tasawuf mereka pilih sebagai pelarian dari kondisi kehancuran ketika itu. Celakanya lagi, justru sikap pasif ini merambah kepada golongan intelektual Islam kala itu. Akibatnya terjadi kemandulan produktifitas ilmiah di kalangan ilmuaan-ilmuan Islam, hal ini dapat terlihat dari miskinnya buku atau karya umat Islam saat itu.

Kendati demikian, banyak sejarawan yang "mengkambing hitamkan" tasawuf sebagai penyebab kemunduran peradaban Islam. Alasan ini tentu mempunyai dalil, tetapi sesungguhnya penyebab kemunduran pendidikan Islam itu tidak tunggal, banyak faktor lain yang menjadi penyebabnya. Hemat penulis tasawuf positif sebagaimana telah dijelaskan pada mukaddimah makalah ini, harus tetap ada dan dikaji dalam pendidikan Islam, karena apa yang menjadi tujuan dari pendidikan Islam sama dengan tujuan tasawuf yaitu mendekatkan diri kepada Allah untuk mencapai kebahagiaan di dunia dan akhirat.

\section{PENUTUP}

Adalah hal yang patut disukuri bahwa perkembangan tasawuf hari ini tidak hanya diminati di dunia Timur (Islam) saja, akan tetapi dunia Barat pun menyambut baik ajaran tasawuf. Bukti-bukti mengenai statement ini telah panjang lebar dijelaskan pada bagian terdahulu. Disamping perlunya melakukan reorientasi tasawuf secara komprehensif bagi umat Islam, paradigma tasawuf yang selama ini terlanjur menjadi stigma buruk di kalangan umat Islam harus dibuang sejauh-jauhnya dengan mengganti menjadi tasawuf positif. Tentunya hal ini memerlukan model dari para ulama, tokoh dan elit Islam. Betapapun sejarah mencatat bahwa tasawuf menjadi salah satu faktor penyebab

${ }^{45}$ Fazlur Rahman, Islam: Sejarah Pemikiran dan Peradaban Terj. M. Irsyad Rafsyadie. (Bandung: Mizan Media Utama, 2017), hlm. 193-194. 
kemunduran peradaban Islam bahkan kevakuman dalam segala bidang, pendidikan Islam khususnya atau umat Islam umumnya masih memerlukan tasawuf sebagai "rem" dalam hidup dan kehidupan. Dalam bidang pendidikan, sesungguhnya apa yang menjadi tujuan dari tasawuf berbanding lurus dengan tujuan pendidikan Islam yaitu memperoleh keridoan Allah swt. demi mencapai kebahagiaan di dunia dan akhirat. 
FITRAH Jurnal Kajian Ilmu-ilmu Keislaman

Vol. 04 No. 1 Juni 2018

\section{DAFTAR PUSTAKA}

Ahmad. 2014, Epistemologi Ilmu-ilmu Tasawuf, Ilmu Ushuluddin, Vol 14, hal 6364.

Anwar, Rosihon, Mukhtar Solihin, 2000, Ilmu Tasawuf, Pustaka Setia. Bandung

Asari, Hasan, 2012, Nukilan Pemikiran Islam Klasik: Gagasan Pendidikan Abu Hamid Al-Ghazali, IAIN Press, Medan.

Depdiknas, 1989, Kamus Besar Bahasa Indonesia, Balai Pustaka, Jakarta.

Ernst, Carl W., 1997, Sufism: an Essential Introduction to the Philosophy and Practice of the Tradition of Islam, Shambhala Publication, USA.

Hadi, Sofyan, 2015, Sintesa Tasawuf Akhlaki dan Falsafi di Nusantara dalam Teks al-Manhal, Jurnal Al-Qalam, Vol. 21, hal 53.

Hamka, 1983, Tasawuf Modern, Pustaka Panjimas, Jakarta.

Hidayat, Komaruddin, 2001, Agama di Tengah Kemelut, Mediacita, Jakarta.

Hasan, Masdul, 20017, History of Islam: Classical Period 571-1258 C.E., Adam Publisher, New Delhi

Lippman, Thomas W, 1995, Understanding Islam: An Introduction to the Muslim World, Penguin Group, New York.

Nasr, Seyyed Hossein, 1999, Sufi Essays, ABC International Group, USA.

Nasution, Harun, 1995, Filsafat dan Mistisme dalam Islam, Bulan Bintang, Jakarta. 2002, Islam Ditinjau dari Berbagai Aspeknya, UI Press, Jakarta.

Nata, Abuddin, 1994, Ilmu Kalam: Filsafat dan Tasawuf, Rajawali, Jakarta.

Nicholson, Reynold A, The Mistics of Islam, George Bell, London.

Nilyati. Sistem Pembinaan Akhalak dalam Tasawuf Akhlaki, Jurnal Tajdid, Vol. 8, hal 76

Rahman, Fazlur, 2017, Islam: Sejarah Pemikiran dan Peradaban, diterjemahkan oleh M. Irsyad Rafsyadie. Mizan Media Utama, Bandung. 
Sholikhin, Muhammad, 2013, Sufi Modern: Mewujudkan Kebahagiaan Menghilangkan Keterasingan, Kompas Gramedia, Jakarta.

Siddik, Dja'far, Ja'far, Jejak langkah Intelektual Islam: Epistemologi: Tokoh dan Karyanya, IAIN Press, Medan.

Suriasumantri, Yuyun, 1996 Filsafat Ilmu: Sebuah Pengantar Populer, Pustaka Sinar Harapan, Jakarta.

Tafsir, Ahmad, 2006, Filsafat Ilmu: Mengurai Ontologi, Epistemologi dan Aksiologi Pengetahuan, Remaja Rosdakarya, Bandung.

Tim Penyusun Proyek Pembinaan Perguruan Tinggi Islam IAIN Sumatera Utara, t.t., Pengantar Ilmu Tasawuf, Naspar Djaja, Medan. 
FITRAH Jurnal Kajian Ilmu-ilmu Keislaman

Vol. 04 No. 1 Juni 2018

Meningkatkan Hasil Belajar Peserta Didik Melalui Model

Tadzkirah Berbasis Masalah di Kelas VII-7 SMP Negeri 2

Padangsidimpuan Tahun Pelajaran

2017/2018

Mulkeis

Guru SMP Negeri 2 Padangsidimpuan, 